\title{
RUMINAL FERMENTATION KINETICS OF MORINGA AND PELTIPHYLLUM SUPPLEMENTS DURING EARLY INCUBATION PERIOD IN THE IN VITRO READING PRESSURE TECHNIQUE
}

\author{
A. Jayanegara',*, T. Sabhan ${ }^{1}$, A.K. Takyi ${ }^{1}$, A.O. Salih ${ }^{1}$ and E.M. Hoffmann ${ }^{2}$ \\ ${ }^{1}$ Agricultural Sciences in the Tropics and Subtropics (AgriTropics), \\ University of Hohenheim, Stuttgart - Germany \\ ${ }^{2}$ Institute for Animal Production in the Tropics and Subtropics (480b), \\ University of Hohenheim, Fruwirthstrasse 12, 70593 Stuttgart - Germany \\ * Permanent address: Faculty of Animal Science, Bogor Agricultural University, \\ Jl. Agatis Kampus IPB Darmaga Bogor 16680 - Indonesia \\ Corresponding E-mail: anu_jayanegara@yahoo.com
}

Received June 12, 2010; Accepted August 28, 2010

\begin{abstract}
This experiment was aimed to observe rumen fermentation kinetics of alternative supplements, i.e. Moringa oleifera and Peltiphyllum peltatum leaves added to maize silage diet as compared to a conventional supplement (barley-soya). A total of six treatments were investigated in the present study, which consisted of: maize silage (A), M. oleifera (B), P. peltatum (C), maize silage + concentrate (56:44, $\mathrm{w} / \mathrm{w} ; \mathrm{D})$, maize silage $+M$. oleifera $(56: 44, \mathrm{w} / \mathrm{w} ; \mathrm{E})$, and maize silage + concentrate $+P$. peltatum $(47: 37: 16, \mathrm{w} / \mathrm{w} / \mathrm{w} ; \mathrm{F})$. The feeds were incubated in vitro in three replicates (completely randomized) using the Reading Pressure Technique system. Approximately $800 \mathrm{mg}$ of the feeds were mixed by $75 \mathrm{ml}$ of buffered rumen liquor. The incubation was carried out up to $12 \mathrm{~h}$ in bottles and gas pressure was recorded and released in regular intervals. Repeated sampling was conducted for analysis of fermentation products at 1,6 and $12 \mathrm{~h}$ of incubation period. The results showed that the nutritional quality of Moringa and its fermentation pattern was comparable to that of barley-soya concentrate. Plain Moringa incubation resulted the highest production of iso-SCFA and soluble protein concentration among all treatments after $12 \mathrm{~h}$ incubation $(\mathrm{P}<0.05)$. Incubation of sole Peltiphyllum peltatum highly hampered the fermentation rate. Production of iso-SCFA both for plain Peltiphyllum and its mixture were comparatively low. Supplementation of Peltiphyllum increased significantly soluble protein concentration during $12 \mathrm{~h}$ incubation $(\mathrm{P}<0.05)$. Peltiphyllum also had a very low $\mathrm{C}_{2}+\mathrm{C}_{4} / \mathrm{C}_{3}$ ratio compared to other treatments. It could be concluded that Moringa oleifera is a potential alternative supplement to replace either partially or completely concentrate as a conventional supplement, and Peltiphyllum peltatum supplementation could reduce excessive protein degradation and fermentation of the concentrate in the rumen.
\end{abstract}

Keywords: Moringa oleifera, Peltiphyllum peltatum, rumen, supplement, tannin,

\section{INTRODUCTION}

Supplementation to forage based diet is necessary to provide adequate nutrient supply, especially for high producing ruminants (Jayanegara and Sofyan, 2009). So far concentrate is the commonest supplement used (Bargo et al., 2002; Steinshamn et al., 2006). However, high cost of concentrate may limit its use as a supplement particularly for small-holder farmers and, therefore, alternative supplement needs to be introduced. Although it has been shown that some alternative supplements from Leucaena leucocephala and Gliricidia sepium leaves were inferior as compared to conventional concentrate (Jayanegara and Sofyan, 2009), screening of such alternative supplements from plant leaves is important to be further extended.

Moringa oleifera is a typical multipurpose tree possessing significant economic importance since various industrial and medicinal products could be derived from its leaves and fruits (Soliva et al., 2005). Moringa leaves have been reported to contain high level of crude protein, i.e. 25.1 and $43.5 \% \mathrm{DM}$ for unextracted and ethanol extracted leaves, respectively (Makkar and Becker, 1996). Moreover, about $95 \%$ of the total crude protein was found to be available either 
ruminally or post-ruminally. The protein potentially digestible in the intestine (PDI) was $47 \%$ and $50 \%$ of the total crude protein for the unextracted and extracted leaves, respectively, and these values were much higher than those for various conventional protein supplements like coconut meals, cottonseed, groundnut, sesame and sunflower. The essential amino acid composition of the leaves was also comparable with that of soybean (Makkar and Becker, 1996). These indicate that Moringa is potential as an alternative supplement.

This experiment was aimed to observe rumen fermentation kinetics when maize silage diet was added a conventional supplement (barley-soya) and an alternative supplement (Moringa oleifera leaves). In addition, the additive effect of Peltiphyllum peltatum as high phenols and tannins leaves (Jayanegara and Sofyan, 2008) was observed in comparison with silage+conventional supplement. It was hypothesized that the addition of tannincontaining forage might prevent excessive degradation of protein in the rumen and, hence, increasing the proportion of available protein in the small intestine. To clarify the effect of each feed, plain maize silage, Moringa and Peltiphyllum leaves were also incubated.

\section{MATERIALS AND METHODS}

\section{Treatments}

Prior to in vitro incubation, all feeds were oven dried at $60{ }^{\circ} \mathrm{C}$ for $24 \mathrm{~h}$ and ground to pass a $1 \mathrm{~mm}$ sieve. A total of six treatments were investigated in the present study using maize silage as the basal feed. Leaves of Moringa oleifera and Peltiphyllum peltatum were used as alternative supplements, in addition to concentrate, which was a mixture of barley grain and soybean meal $(57: 43, \mathrm{w} / \mathrm{w})$. The treatments consisted of:
A : Maize silage
B : M. oleifera
C: P. peltatum
D : Maize silage + concentrate $(56: 44, w / w)$
E : Maize silage + M. oleifera $(56: 44, \mathrm{w} / \mathrm{w})$
$\mathrm{F}$ : Maize silage + concentrate $+P$. peltatum (47:37:16, w/w/w)

The feeds were analyzed for their chemical composition. This included proximate analysis, cell wall content and phenolic fraction determinations. For the proximate analysis, dry matter (DM), organic matter (OM), crude ash (CA), crude protein (CP) and ether extract (EE) were analyzed according to AOAC (1990). Cell wall content, i.e. neutral detergent fiber (NDF) and acid detergent fiber (ADF) was determined based on Van Soest et al. (1991). For the phenol assays, samples were ground to fine powder in a Ballmill MM 200 (Retsch GmbH, Haan, Germany) at $50 \mathrm{~Hz}$ for $2 \mathrm{~min}$. Samples $(0.2 \mathrm{~g})$ were extracted in $10 \mathrm{ml}$ aqueous acetone (acetone:water, 7:3) twice for $20 \mathrm{~min}$ in an ultrasonic waterbath. The extracted samples were centrifuged $\left(4000 \times g, 10 \mathrm{~min}, 4^{\circ} \mathrm{C}\right)$, and the supernatants were combined and used for phenol analysis. Phenol assays were according to Makkar (2003). Total phenols (TP) and total tannins (TT) in the extract were determined by a modification of the Folin-Ciocalteu method using polyvinylpolypyrrolidone (PVPP) to separate tannin phenols from non-tannin phenols. Both TP and TT were expressed as tannic acid equivalent. Summary of the chemical composition of the treatment feeds is presented in the Table 1.

\section{In Vitro Incubation}

In vitro incubation of the feeds was performed using the Reading Pressure Technique system (Mauricio et al., 1999) as modified by Selje-Assmann et al. (2008). All feed treatments were incubated in three replicates using completely randomized design. Rumen fluid was collected before the morning feeding from two fistulated Holstein cows receiving regular hay and concentrate and fed ad libitum in two equal meals per day. The rumen fluid was strained through a $100 \mu \mathrm{m}$ nylon net and diluted with nine volumes of reduced buffer. Aliquots of $75 \mathrm{ml}$ were dispensed into serum bottles containing approximately $800 \mathrm{mg}$ of the feeds. The incubation was carried out up to $12 \mathrm{~h}$ in bottles and gas pressure was recorded and released in regular intervals. The bottles were opened for repeated sampling, i.e. at 1,6 and $12 \mathrm{~h}$ of incubation period, and homogenous aliquots (1 $\mathrm{ml}$ ) were removed under vigorous stirring for analysis of fermentation products. The headspace was flushed by $\mathrm{CO}_{2}$ before the bottles were closed and incubation was continued.

\section{Analysis of Fermentation Products}

Gas production rate and cumulative was recorded from the incubation bottles. The $1 \mathrm{ml}$ of samples (incubation medium containing rumenbuffer mixture) taken at regular intervals were 
Table 1. Chemical Composition of the Treatment Feeds

\begin{tabular}{lcccccc}
\hline & \multicolumn{7}{c}{ Treatments (\% dry matter) } \\
\cline { 2 - 7 } & $\mathrm{A}$ & $\mathrm{B}$ & $\mathrm{C}$ & $\mathrm{D}$ & $\mathrm{E}$ & $\mathrm{F}$ \\
\hline $\mathrm{DM}$ & 91.9 & 92.3 & 92 & 90.1 & 92.1 & 90.4 \\
OM & 96 & 91.2 & 89.3 & 96 & 93.9 & 95 \\
$\mathrm{CA}$ & 4.0 & 8.8 & 10.7 & 4.0 & 6.1 & 5.0 \\
CP & 7.2 & 24 & 11.3 & 15.1 & 14.6 & 14.5 \\
EE & 1.6 & 5.4 & 2.0 & 1.9 & 3.3 & 1.9 \\
NDF & 45.1 & 21.9 & 19.1 & 34.1 & 35 & 31.8 \\
ADF & 24.6 & 11.4 & 18.3 & 18 & 18.8 & 18 \\
TP & 0.0 & 3.4 & 20 & 0.0 & 1.5 & 3.2 \\
TT & 0.0 & 1.4 & 14.7 & 0.0 & 0.6 & 2.3 \\
\hline
\end{tabular}

$\mathrm{A}=$ maize silage $; \mathrm{B}=\mathrm{M}$. oleifera $; \mathrm{C}=\mathrm{P}$. peltatum $; \mathrm{D}=$ maize silage + contretate $(56: 44, \mathrm{w} / \mathrm{w}) ; \mathrm{E}=$ maize silage $+\mathrm{M}$. oleifera $(56: 44, \mathrm{w} / \mathrm{w})$; $\mathrm{F}=$ maize silage + concentrate $+\mathrm{P}$. peltatum $(47: 37: 16, \mathrm{w} / \mathrm{w} / \mathrm{w})$ $\mathrm{DM}=$ dry matter; $\mathrm{OM}=$ organic matter; $\mathrm{CA}=$ crude ash; $\mathrm{CP}=$ crude protein; $\mathrm{EE}=$ ether extract; $\mathrm{NDF}=$ neutral detergent fiber; $\mathrm{ADF}=$ acid detergent fiber; $\mathrm{TP}=$ total phenols; $\mathrm{TT}=$ total tannins

centrifuged at $30,000 \times g$ for $10 \mathrm{~min}$ at $4{ }^{\circ} \mathrm{C}$. These were subjected to short-chain fatty acid (SCFA) and protein analyses. For SCFA analysis, $630 \mu \mathrm{l}$ of supernatant were mixed with $70 \mu$ internal standard $(10 \mathrm{mg} / \mathrm{l}$ methylvaleric acid in formic acid), deproteinized overnight $\left(4^{\circ} \mathrm{C}\right)$. The samples then were centrifuged again and $600 \mu \mathrm{l}$ aliquot of deproteinized supernatant was analyzed by gas chromatography according to Hoeltershinken et al. (1997). The remaining supernatant from the original sample was collected for soluble protein determination by dot blot method as described by Hoffmann et al. (2002). This method is contrast to the commonly used Kjeldahl method since this assay directly determines the true protein while not detecting non-protein nitrogen, small oligopeptides or free amino acids.

\section{Statistical analysis}

Data obtained were subjected to one-way analysis of variance (ANOVA), followed by Duncan's multiple range test (DMRT) to allow comparison among means from different treatments (Steel and Torrie, 1980). This was performed using SPSS statistical package version 17.0. Graphs presented were generated by MS Excel 2003.

\section{RESULTS AND DISCUSSION}

\section{Rate and cumulative of gas production}

Gas production rate decreased in the first 2.5 $\mathrm{h}$ for all treatments (Figure 1). Microbial adaptation to the newly given feeds was probably the reason. This is one of the drawbacks of any in vitro batch fermentation systems as compared to the in vivo system where rumen microbes have no adaptation period to a newly introduced feed prior to experiment (Williams, 2000; Rymer et al., 2005). The rate of gas production increased after $2.5 \mathrm{~h}$ of incubation period to around $8 \mathrm{~h}$, except the $P$. peltatum incubation (treatment $\mathrm{C}$ ). Within this period, it appeared that microbes have been adapted to the treatments and showed the most active fermentation activity, while $P$. peltatum highly hampered the fermentation rate due to its high TP and TT contents, as confirmed by other studies (Jayanegara and Sofyan, 2008; Jayanegara et al., 2009). Inhibition of P. peltatum on in vitro gas production has also been observed by other authors (Selje-Assmann et al., 2007; Jayanegara et al., 2009). However, Jayanegara et al. (2009) reported that the adverse effect could be neutralized by adding polyethylene glycol (PEG), a tannin binding substance. Moringa showed no negative effect for this variable due to its negligible amount of phenols and tannins (Makkar and Becker, 1996). Gas production rate diminished after 8 hours incubation time perhaps because at this point the end products have been accumulated and hence give negative feedback to the microbial activity.

The pattern of cumulative gas was closely similar to that of the gas production rate since this 
Table 2. Kinetics of Short-chain Fatty Acid (SCFA) Production of the Incubated Feed Treatments

\begin{tabular}{|c|c|c|c|c|c|c|c|c|c|}
\hline \multirow{2}{*}{ SCFA } & \multirow{2}{*}{ Period } & \multicolumn{6}{|c|}{ Treatments } & \multirow{2}{*}{ SEM } & \multirow{2}{*}{ P-value } \\
\hline & & A & $\mathrm{B}$ & $\mathrm{C}$ & $\mathrm{D}$ & E & $\mathrm{F}$ & & \\
\hline & -- h -- & $-\cdots$ & 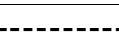 & $-\cdots \mathrm{mN}$ & $-\cdots$ & $-\cdots---$ & --- & & \\
\hline \multirow{3}{*}{$\mathrm{C}_{2}$} & 1 & $7.91^{\mathrm{b}}$ & $8.77^{\mathrm{e}}$ & $7.65^{\mathrm{a}}$ & $8.44^{\mathrm{cd}}$ & $8.53^{\mathrm{d}}$ & $8.33^{\mathrm{c}}$ & 0.12 & $<0.001$ \\
\hline & 6 & $13.60^{\mathrm{b}}$ & $17.56^{\mathrm{c}}$ & $8.94^{\mathrm{a}}$ & $16.91^{\mathrm{c}}$ & $17.47^{\mathrm{c}}$ & 16.78 & 0.94 & $<0.001$ \\
\hline & 12 & $22.88^{\mathrm{b}}$ & $28.37^{\mathrm{d}}$ & $11.06^{\mathrm{a}}$ & $27.46^{\mathrm{c}}$ & $27.18^{\mathrm{c}}$ & $26.80^{\mathrm{c}}$ & 1.82 & $<0.001$ \\
\hline \multirow[t]{3}{*}{$\overline{C_{3}}$} & 1 & $1.90^{\mathrm{b}}$ & $1.89^{\mathrm{b}}$ & $1.62^{\mathrm{a}}$ & $1.99^{d}$ & $1.97^{\mathrm{cd}}$ & $1.92^{\mathrm{bc}}$ & 0.04 & $<0.001$ \\
\hline & 6 & $4.50^{\mathrm{b}}$ & $5.45^{\mathrm{c}}$ & $2.28^{\mathrm{a}}$ & $6.54^{\mathrm{e}}$ & $5.95^{\mathrm{d}}$ & $6.11^{\mathrm{de}}$ & 0.43 & $<0.001$ \\
\hline & 12 & $9.94^{\mathrm{c}}$ & $8.89^{\mathrm{b}}$ & $3.45^{\mathrm{a}}$ & $14.11^{\mathrm{f}}$ & $11.56^{\mathrm{d}}$ & $12.99^{\mathrm{e}}$ & 1.05 & $<0.001$ \\
\hline \multirow[t]{3}{*}{$\mathrm{C}_{4}$} & 1 & $1.31^{\mathrm{b}}$ & $1.35^{\mathrm{cd}}$ & $1.25^{\mathrm{a}}$ & $1.37^{\mathrm{d}}$ & $1.34^{\mathrm{bc}}$ & $1.33^{\mathrm{bc}}$ & 0.01 & 0 \\
\hline & 6 & $2.44^{\mathrm{b}}$ & $2.32^{\mathrm{b}}$ & $1.50^{\mathrm{a}}$ & $2.95^{\mathrm{d}}$ & $2.69^{\mathrm{c}}$ & $2.77^{\mathrm{c}}$ & 0.14 & $<0.001$ \\
\hline & 12 & $4.80^{\mathrm{c}}$ & $3.55^{\mathrm{b}}$ & $1.62^{\mathrm{a}}$ & $5.81^{\mathrm{e}}$ & $4.66^{c}$ & $5.29^{\mathrm{d}}$ & 0.42 & $<0.001$ \\
\hline \multirow[t]{3}{*}{$i_{i s o C_{4}}$} & 1 & 0.09 & 0.1 & 0.09 & 0.1 & 0.1 & 0.1 & 0 & $\mathrm{~ns}$ \\
\hline & 6 & $0.12^{\mathrm{b}}$ & $0.18^{\mathrm{d}}$ & $0.09^{\mathrm{a}}$ & $0.16^{\mathrm{c}}$ & $0.16^{\mathrm{c}}$ & $0.13^{\mathrm{b}}$ & 0.01 & $<0.001$ \\
\hline & 12 & $0.16^{\mathrm{b}}$ & $0.28^{\mathrm{d}}$ & $0.10^{\mathrm{a}}$ & $0.26^{\mathrm{cd}}$ & $0.24^{c}$ & $0.18^{\mathrm{b}}$ & 0.02 & $<0.001$ \\
\hline \multirow[t]{3}{*}{$\mathrm{C}_{5}$} & 1 & $0.09^{\mathrm{b}}$ & $0.09^{\mathrm{b}}$ & $0.08^{\mathrm{a}}$ & $0.09^{\mathrm{b}}$ & $0.09^{\mathrm{b}}$ & $0.09^{b}$ & 0 & 0.01 \\
\hline & 6 & $0.19^{\mathrm{c}}$ & $0.17^{\mathrm{b}}$ & $0.09^{\mathrm{a}}$ & $0.23^{e}$ & $0.20^{\mathrm{d}}$ & $0.17^{\mathrm{b}}$ & 0.01 & $<0.001$ \\
\hline & 12 & $0.29^{\mathrm{b}}$ & $0.35^{\mathrm{c}}$ & $0.09^{\mathrm{a}}$ & $0.47^{\mathrm{e}}$ & $0.37^{\mathrm{d}}$ & $0.29^{b}$ & 0.03 & $<0.001$ \\
\hline \multirow[t]{3}{*}{ isoC $_{5}$} & 1 & $0.14^{\mathrm{b}}$ & $0.14^{\mathrm{b}}$ & $0.12^{\mathrm{a}}$ & $0.13^{\mathrm{ab}}$ & $0.14^{\mathrm{b}}$ & $0.13^{\mathrm{ab}}$ & 0 & 0 \\
\hline & 6 & $0.18^{b}$ & $0.25^{\mathrm{c}}$ & $0.12^{\mathrm{a}}$ & $0.26^{c}$ & $0.25^{\mathrm{c}}$ & $0.17^{\mathrm{ab}}$ & 0.02 & 0 \\
\hline & 12 & $0.20^{\mathrm{b}}$ & $0.45^{\mathrm{e}}$ & $0.12^{\mathrm{a}}$ & $0.41^{\mathrm{d}}$ & $0.36^{c}$ & $0.18^{\mathrm{b}}$ & 0.04 & $<0.001$ \\
\hline \multirow[t]{3}{*}{ Total SCFA } & 1 & $11.45^{\mathrm{b}}$ & $12.34^{\mathrm{d}}$ & $10.82^{\mathrm{a}}$ & $12.13^{\mathrm{cd}}$ & $12.17^{\mathrm{d}}$ & $11.88^{\mathrm{c}}$ & 0.16 & $<0.001$ \\
\hline & 6 & $21.03^{b}$ & $25.93^{c}$ & $13.02^{\mathrm{a}}$ & $27.04^{\mathrm{c}}$ & $26.74^{\mathrm{c}}$ & $26.13^{\mathrm{c}}$ & 1.52 & $<0.001$ \\
\hline & 12 & $38.27^{\mathrm{b}}$ & $41.89^{\mathrm{c}}$ & $16.46^{\mathrm{a}}$ & $48.51^{\mathrm{f}}$ & $44.37^{\mathrm{d}}$ & $45.73^{\mathrm{e}}$ & 3.21 & $<0.001$ \\
\hline \multirow[t]{3}{*}{ isoSCFA } & 1 & $0.23^{b}$ & $0.24^{\mathrm{c}}$ & $0.21^{\mathrm{a}}$ & $0.23^{b}$ & $0.24^{\mathrm{c}}$ & $0.23^{\mathrm{b}}$ & 0 & 0 \\
\hline & 6 & $0.30^{\mathrm{b}}$ & $0.43^{c}$ & $0.21^{\mathrm{a}}$ & $0.42^{\mathrm{c}}$ & $0.41^{\mathrm{c}}$ & $0.30^{\mathrm{b}}$ & 0.03 & $<0.001$ \\
\hline & 12 & $0.36^{\mathrm{b}}$ & $0.73^{\mathrm{d}}$ & $0.22^{\mathrm{a}}$ & $0.67^{\mathrm{d}}$ & $0.60^{c}$ & $0.36^{\mathrm{b}}$ & 0.06 & $<0.001$ \\
\hline
\end{tabular}

Different superscript in the same row shows significantly different at at least $\mathrm{P}<0.05$

$\mathrm{C}_{2}=$ acetate; $\mathrm{C}_{3}=$ propionate; $\mathrm{C}_{4}=$ butyrate; iso $\mathrm{C}_{4}=$ is obutyrate; $\mathrm{C}_{5}=$ valerate; iso $\mathrm{C}_{5}=$ isovalerate

figure was derived from the latter by adding up the value for each incubation time. The fermentation still occurred up to 12 hours incubation time, not yet reached the lag phase of microbial activity. Such asymptotic cumulative gas production in the batch in vitro system could nearly be reached after 72 to $96 \mathrm{~h}$ after incubation (Menke and Steingass, 1988; Williams, 2000). Comparing the cumulative gas production of maize silage and $M$. oleifera, the silage produced a little bit higher gas although Moringa contained higher soluble nutrients (higher $\mathrm{CP}$ and lower NDF and ADF; Table 1). This might be related to the fact that $\mathrm{CP}$ stoichiometrically contributes to much less gas production as compared to carbohydrate fractions (Getachew et al., 1998). Therefore, multiple regression equation of organic matter digestibility (OMD) does not contain only cumulative gas production variable but also $\mathrm{CP}$ variable (Menke and Steingass, 1988). The addition of conventional supplement (barley-soya) to maize silage increased the cumulative gas production than that of plain maize silage since the concentrate contained more easily degradable nutrients as also reported by Mulligan et al. (2004). Moringa leaves as an alternative supplement seemed to have comparable quality like the concentrate since the gas production up to $12 \mathrm{~h}$ of incubation period was closely similar. Again, the addition of Peltiphyllum to silage and conventional concentrate decreased the gas production due to the additive effect of phenols and tannins.

\section{Kinetics of Short-chain Fatty Acids Profile and Soluble Protein}

In general, all short-chain fatty acid (SCFA) concentrations increased during the fermentation 

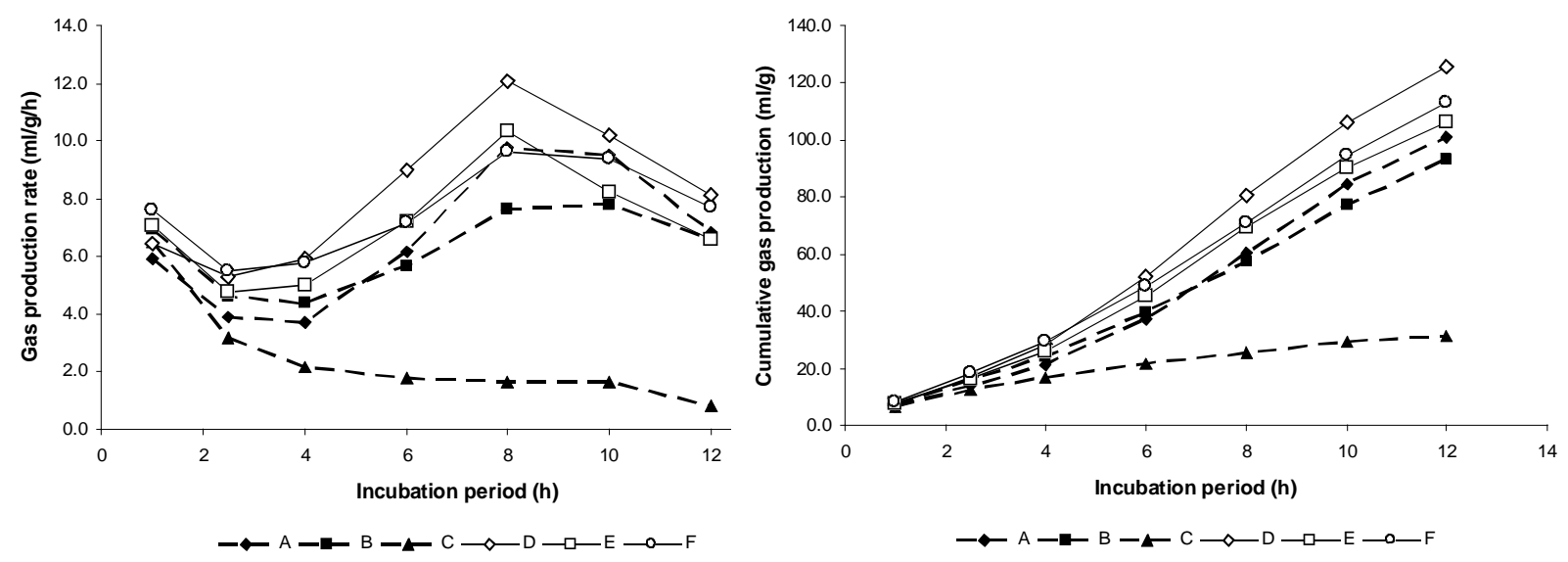

Figure 1. Rate (a) and Cumulative of Gas Production (b) of the Treatment Feeds during $12 \mathrm{~h}$ Incubation. $\mathrm{A}=$ maize silage; $\mathrm{B}=M$. oleifera $; \mathrm{C}=P$. peltatum; $\mathrm{D}=$ maize silage + concentrate $(56: 44, \mathrm{w} / \mathrm{w})$; $\mathrm{E}=$ maize silage $+M$. oleifera $(56: 44, \mathrm{w} / \mathrm{w}) ; \mathrm{F}=$ maize silage + concentrate $+P$. peltatum $(47: 37: 16, \mathrm{w} / \mathrm{w} / \mathrm{w})$

from 1 to $12 \mathrm{~h}$. During fermentation, carbohydrate (sugars, starch, and part of fiber) and protein are degraded and converted to SCFA such as acetate, propionate and butyrate (Baldwin and Allison, 1983; Bach et al., 2005). Iso-SCFA such as isobutyrate and iso-valerate are the specific products of protein fermentation, particularly from deamination of branched chain amino acids (Hoffmann et al., 2008). Therefore this variable indicates the extent of protein degradation in the rumen. Production of iso-SCFA both for plain Peltiphyllum and its mixture were comparatively low. Peltiphyllum contains tannins which can bind protein and partially prevent the protein from ruminal degradation and fermentation (MuellerHarvey, 2006). This complex can be further degraded in the abomasum under acidic condition and hence increasing the amount of by-pass protein (Makkar et al., 2007). Such condition is favourable when animals are fed with high quality feed with high amount of soluble nutrients, particularly high quality protein. The plain Moringa incubation showed the highest production of iso-SCFA since the $\mathrm{CP}$ content is the highest among the treatments (24\% DM). This is the same reason to explain the low iso-SCFA production from plain maize silage incubation which contains very low crude protein $(7.2 \%$ DM). The iso-SCFA pattern was confirmed by the kinetics of soluble protein concentration (Figure 2).

Acetate and butyrate are mainly produced as end products of high fiber diet (high activity of cellulolytic bacteria) while propionate is a major end product of low fiber diet (high activity of amylolytic bacteria) (Rodriguez-Prado et al., 2004). The ratio of $\mathrm{C}_{2}+\mathrm{C}_{4} / \mathrm{C}_{3}$ shows the occurrence of these end products in a relative form (Figure 3). In general, the ratio increased over incubation period. In the beginning of fermentation, amylolytic and saccharolytic degrading microorganisms played a major role over fiber degrading microorganims due to the easily degraded and fermented starch and sugar, respectively. Hence, the ratio was low and reflected the relatively high concentration of propionate. When sugar and starch were depleted, fiber degradation took over the major role of fermentation, and acetate and butyrate became predominant over propionate. Among the treatments, most of them were not different except

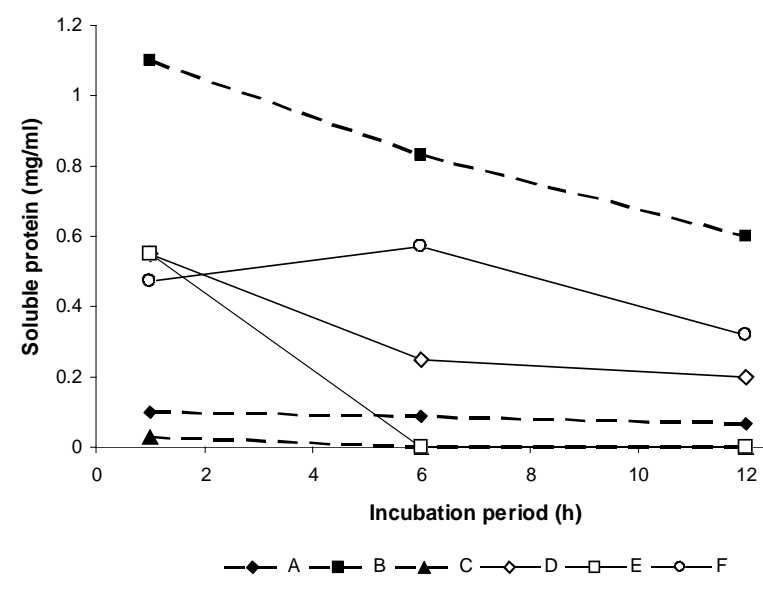

Figure 2. Kinetics of Soluble Protein Concentration in the Incubation Medium of the Treatment Feeds 


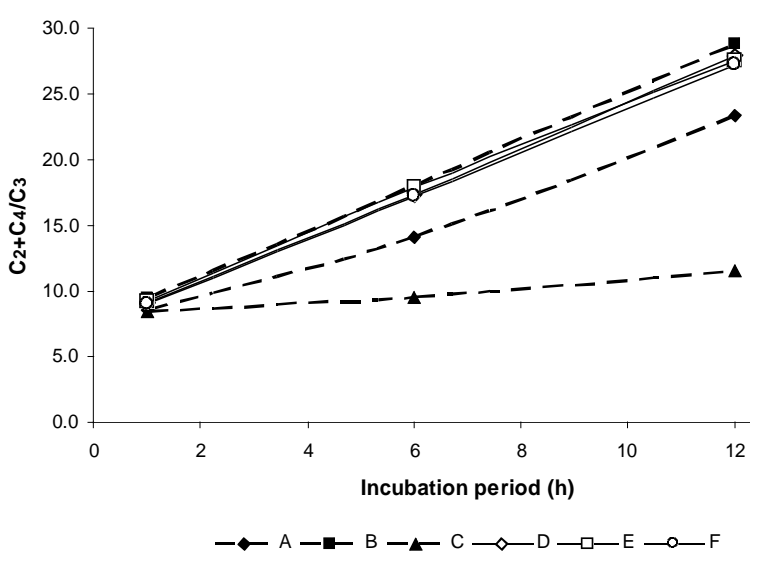

Figure 3. Kinetics of $\mathrm{C}_{2}+\mathrm{C}_{4} / \mathrm{C}_{3}$ Ratio in the Incubation Medium of the Treatment Feeds

for maize silage and plain Peltiphyllum treatments $(\mathrm{P}<0.05)$. Maize silage has comparatively low soluble nutrients such as sugar and starch and hence lowering the ratio $\mathrm{C}_{2}+\mathrm{C}_{4} / \mathrm{C}_{3}$. In the case of Peltiphyllum, it was obvious that the ratio was very low. It might be that protein degradation was hampered by the action of phenols and tannins, and it might be also that these substances inhibited the overall fermentation processes.

\section{CONCLUSION}

Moringa oleifera is a potential alternative supplement to replace either partially or completely the conventional supplement i.e. concentrate. The nutritional quality of Moringa and its fermentation pattern was comparable to that of barley-soya concentrate. Peltiphyllum peltatum could reduce excessive protein degradation and fermentation of the concentrate in the rumen and, therefore, may increase the amount of ruminal by-pass protein for further enzymatic degradation in the small intestine. However, incubation of sole Peltiphyllum hampered severely the fermentation due to its high phenolic content. This suggested that the plant could not be given at a high concentration in a mixture diet, but rather a small proportion instead by considering the phenolic concentration in the mixture.

\section{REFERENCES}

AOAC. 1990. Official Methods of Analysis. $15^{\text {th }}$ ed. Association of Official Analytical Chemists, Arlington, VA, USA.
Bach, A., S. Calsamiglia and M.D. Stern. 2005. Nitrogen metabolism in the rumen. J. Dairy Sci. 88: E9-E21.

Baldwin, R.L., and M.J. Allison. 1983. Rumen metabolism. J. Anim. Sci. 57: 461-477.

Bargo, F., L.D. Muller, J.E. Delahoy and T. W. Cassidy. 2002. Milk response to concentrate supplementation of high producing dairy cows grazing at two pasture allowances. J. Dairy Sci. 85: 1777-1792.

Getachew, G., M. Blummel, H.P.S. Makkar and K. Becker. 1998. In vitro measuring techniques for assessment nutritional quality of feeds: a review. Anim. Feed Sci. Technol. 72: 261281.

Hoeltershinken, M., U. Plitt, F.C. Tammen, P. Hoffmann and H. Scholz. 1997. Influence of mouldy grass on fermentation and thiamine metabolism in bovine rumen fluid (in vitro). Deutsche Tierärztliche Wochenschrift 104: 17-22.

Hoffmann, E.M., S. Muetzel and K. Becker. 2002. A modified dot-blot method of protein determination applied in the tannin-protein precipitation assay to facilitate the evaluation of tannin activity in animal feeds. Br. J. Nutr. 87: 421-426.

Hoffmann, E.M., N. Selje-Assmann and K. Becker. 2008. Dose studies on antiproteolytic effects of a methanol extract from Knautia arvensis on in vitro ruminal fermentation. Anim. Feed Sci. Technol. 145: 285-301.

Jayanegara, A., and A. Sofyan. 2008. Penentuan aktivitas biologis tanin secara in vitro menggunakan Hohenheim gas test dengan polietilen glikol sebagai determinan. Media Peternakan 31: 44-52.

Jayanegara, A., and A. Sofyan. 2009. Supplementary feeding on the nutrient balance of lactating dairy cow at contrasting temperature regimes: assessment using Cornell Net Carbohydrate and Protein System (CNCPS) model. J. Indon. Trop. Anim. Agric. 34: 196-204.

Jayanegara, A., N. Togtokhbayar, H.P.S. Makkar and K. Becker. 2009. Tannins determined by various methods as predictors of methane production reduction potential of plants by an in vitro rumen fermentation system. Anim. Feed Sci. Technol. 150: 230-237.

Makkar, H.P.S., and K. Becker. 1996. Nutritional value and antinutritional components of whole and ethanol extracted Moringan 
oleifera leaves. Anim. Feed Sci. Technol. 63: 211-228.

Makkar, H.P.S. 2003. Quantification of Tannins in Tree and Shrub Foliage: A Laboratory Manual. Kluwer Academic Publishers, Dordrecht, The Netherlands.

Makkar, H.P.S., G. Francis and K. Becker. 2007. Bioactivity of phytochemicals in some lesser-known plants and their effects and potential applications in livestock and aquaculture production systems. Animal 1: 1371-1391.

Mauricio, R.M., F.L. Mould, M.S. Dhanoa, E. Owen, K.S. Channa and M.K. Theodorou. 1999. A semi-automated in vitro gas production technique for ruminant feedstuff evaluation. Anim. Feed Sci. Technol. 79: 321-330.

Menke, K.H., and H. Steingass. 1988. Estimation of the energetic feed value obtained from chemical analysis and in vitro gas production using rumen fluid. Anim. Res. Dev. 28: 7-55.

Mueller-Harvey, I. 2006. Unravelling the conundrum of tannins in animal nutrition and health. J. Sci. Food Agric. 86: 2010-2037.

Mulligan, F.J., P. Dillon, J.J. Callan, M. Rath and F.P. O'Mara. 2004. Supplementary concentrate type affects nitrogen excretion of grazing dairy cows. J. Dairy Sci. 87: 34513460.

Rodriguez-Prado, M., S. Calsamiglia and A. Ferret. 2004. Effects of fiber content and particle size of forage on the flow of microbial amino acids from continuous culture fermenters. J. Dairy Sci. 87: 14131424.

Rymer, C., J.A. Huntington, B.A. Williams and D.I. Givens. 2005. In vitro cumulative gas production techniques: History, methodological considerations and challenges. Anim. Feed Sci. Technol. 123124: 9-30.

Selje-Assmann, N., E.M. Hoffmann, S. Muetzel, R. Ningrat, R.J. Wallace and K. Becker. 2007. Results of a screening programme to identify plants of plant extracts that inhibit ruminal protein degradation. Br. J. Nutr. 98: 45-53.

Selje-Assmann, N., E.M. Hoffmann and K. Becker. 2008. A batch incubation assay to screen additives for their ability to inhibit rumen protein degradation. Anim. Feed Sci. Technol. 145: 302-318.

Soliva, C.R., M. Kreuzer, N. Foidl, G. Foidl, A. Machmuller and H.D. Hess. 2005. Feeding value of whole and extracted Moringa oleifera leaves for ruminants and their effects on ruminal fermentation in vitro. Anim. Feed Sci. Technol. 118: 47-62.

Steel, R.G.D., and J.H. Torrie. 1980. Principles and Procedures of Statistics: a Biometrical Approach. McGraw-Hill, New York, USA.

Steinshamn, H., M. Hoglind, T.H. Garmo, E. Thuen and U.T. Brenoe. 2006. Feed nitrogen conversion in lactating dairy cows on pasture as affected by concentrate supplementation. Anim. Feed Sci. Technol. 131: 25-41.

Van Soest, P.J., J.B. Robertson and B.A. Lewis. 1991. Methods for dietary fiber, neutral detergent fiber and non starch polysaccharides in relation to animal nutrition. J. Dairy Sci. 74: 3583-3597.

Williams, B.A. 2000. Cumulative gas production techniques for forage evaluation. In: Forage Evaluation in Ruminant Nutrition. (D.I. Givens, R. Owen, R.F.E. Axford, and H.M. Omed, eds). CABI Publishing, Oxon, UK. P. 189-213. 